\title{
Creation of an Electronic Textbook for University Students
}

\section{Creación de un libro de texto electrónico para estudiantes universitarios.}

\author{
Sergeeva M.G.
}

Research Institute of the Federal Penitentiary Service of Russia, Russia

ORCID: https://orcid.org/0000-0001-9042-7988

\author{
Spitsyna N.A.
}

Far Eastern Federal University, Russia

ORCID: https://orcid.org/0000-0002-1267-7794

\section{Zuykov A.V.}

Peoples' Friendship University of Russia, Russia ORCID: https://orcid.org/0000-0002-7399-7804

\section{Popov K.I.}

Russian University of Transport, Russia

ORCID: https://orcid.org/0000-0002-9076-4949

\section{Sannikova N.I.}

Yugra State University, Russia

ORCID: https://orcid.org/0000-0002-7724-8907

Tsakhaeva A.A.

Dagestan State Pedagogical University, Russia ORCID: https://orcid.org/0000-0002-0731-7284

Received 04-12-20 Revised 01-25-20 Accepted 05-12-20 On line 06-30-20

*Correspondence

Email: nii@fsin.su
Cite as:

Sergeeva M.G., Spitsyna N.A., Zuykov A.V., Popov K.I., Sannikova N.I., \& Tsakhaeva A.A. (2020). Creation of an Electronic Textbook for University Students. Propósitos y Representaciones, 8 (SPE2), e629. Doi: http://dx.doi.org/10.20511/pyr2020.v8nSPE2.629 


\section{Summary}

The need for e-learning in modern Russia is caused by the rapid development of informatization, digitalization, information and communication technologies, the creation of a global environment for mutual integration of cultures and disciplines, as well as the formation of open continuous education, which is the basis of a post-industrial (information) society. These processes stimulate an active search for creative educational practices that meet the requirements of the information society. A modern specialist must have a certain amount of knowledge that will allow him to learn constantly, improve his skills and abilities, self-develop and self-actualize in order to keep up with the time of changes in the information society. In the framework of the modern educational paradigm, the student is considered as a subject of knowledge, not an object of pedagogical influence. In the early - mid-2010s, this is actively promoted by electronic learning (e-learning, EL), which should be used in various educational organizations. E-learning allows integrating into the world scientific community, becoming subjects of interaction between cultures, including the exchange of spiritual values. Implementation of EL is one of the key tasks in the context of modernization of national education. The term "electronic learning" is translated into Russian in various ways. The most popular options are: "distance learning/education", "mobile learning", and "virtual learning". The European Commission interprets "e-learning" as "using new multimedia and Internet technologies to improve the quality of learning by improving access to resources and services, as well as remote knowledge sharing and collaboration". In this study, the concept of "elearning" will correspond to the phrase "electronic learning". This is an educational process based on interactive electronic means of storing and providing information: the Internet, corporate networks, and CDs.

Keywords: Electronic Learning; Electronic Textbook; Individualized Active Educational Environment; Didactic Features of the E-Textbook.

\section{Resumen}

La necesidad de aprendizaje electrónico en la Rusia moderna está causada por el rápido desarrollo de las tecnologías de información, digitalización, información y comunicación, la creación de un entorno global para la integración mutua de culturas y disciplinas, así como la formación de una educación abierta continua, que es la base de una sociedad postindustrial (de información). Estos procesos estimulan una búsqueda activa de prácticas educativas creativas que cumplan con los requisitos de la sociedad de la información. Un especialista moderno debe tener una cierta cantidad de conocimiento que le permita aprender constantemente, mejorar sus habilidades y destrezas, desarrollarse y actualizarse para mantenerse al día con los cambios en la sociedad de la información. En el marco del paradigma educativo moderno, el estudiante es considerado como un sujeto de conocimiento, no un objeto de influencia pedagógica. A principios de mediados de 2010, esto se promueve activamente mediante el aprendizaje electrónico (e-learning, EL), que debe utilizarse en varias organizaciones educativas. El e-learning permite integrarse en la comunidad científica mundial, convirtiéndose en sujetos de interacción entre culturas, incluido el intercambio de valores espirituales. La implementación de EL es una de las tareas clave en el contexto de la modernización de la educación nacional. El término "aprendizaje electrónico" se traduce al ruso de varias maneras. Las opciones más populares son: "educación a distancia / educación", "aprendizaje móvil" y "aprendizaje virtual". La Comisión Europea interpreta el "e-learning" como "el uso de nuevas tecnologías multimedia e Internet para mejorar la calidad del aprendizaje al mejorar el acceso a los recursos y servicios, así como el intercambio y la colaboración de conocimientos a distancia". En este estudio, el concepto de "elearning" corresponderá a la frase "aprendizaje electrónico". Este es un proceso educativo basado en medios electrónicos interactivos para almacenar y proporcionar información: Internet, redes corporativas y $\mathrm{CD}$.

Palabra clave: Aprendizaje electrónico; Libro de texto electrónico; Ambiente educativo activo individualizado; Características didácticas del libro de texto electrónico. 


\section{Introduction}

The country's competitiveness in the modern world is the most important criterion for the development of the state and ensuring national security. Russia is actively implementing information technologies in all spheres of society and human activity through the verification of national projects, for example, the national project "Education" is aimed at improving the competitiveness of Russian education. Russia is scheduled to enter the top ten countries in the world in terms of quality of education by 2024 . One of the goals is to "create a modern and secure digital educational environment by 2024 that ensures high quality and accessibility of education of all types and levels" and "modernization of professional education".

Modern university education is carried out in an information and educational environment (hereinafter - IEE), which includes such educational resources as electronic libraries, video and online courses, and electronic textbooks.

An electronic textbook (hereinafter - ET) is a digital learning tool that contains a systematic and complete presentation of the subject or part of it, ensuring the completeness of the didactic cycle of the learning process, creating an individualized active educational environment (Makarova, 2019; Abuzjarova, 2018; Ashmarov, 2018; Aminova \& Tsakhaeva, 2018; Badakhova, 2017; Bolotin et al., 2017; Borisov, 2018).

Since 2017, an information portal has been functioning that provides practical implementation of the project "Modern digital educational environment in the Russian Federation". More than 30 online educational platforms, more than 120 universities interact online, and more than 1000 registered online courses are offered. The analysis of information portals of leading Russian universities allows to state the insufficient availability of electronic textbooks that correspond to the definition of an electronic textbook, the purpose of which is to automate the control of students' knowledge, the implementation of feedback between the teacher and the student (Borisova et al., 2018; Borovikova, 2017; Bugreeva, 2019; Gadzaov \& Dzerzhinskaya, 2018; Gadzhieva, 2018; Gasanova et al., 2017; Gnatyuk \& Pekert, 2018; Korotkov, (2019; Kryuchkova, 2018; Kuznetsov et al., 2018).

In accordance with the Federal Law "On amendments to the law of the Russian Federation "On education in the Russian Federation" regarding the use of e-learning and distance education technologies" (28.02.2012. № 11-FZ), e-learning is carried out according to certain requirements (Figure 1).

E-learning is the organization of the educational process using:

information contained in databases and used in the implementation of educational programs

information technologies and technical means for processing this information

information and communication networks, through which the necessary data is transmitted via communication lines and interaction of participants in the educational process

Figure 1. Requirements for e-learning organization 
The development of e-learning is presented in table 1 .

Table 1.

Stages of electronic learning

\begin{tabular}{|c|c|c|}
\hline № & Stage & Description \\
\hline 1. & Distance learning & $\begin{array}{l}\text { The origin of distance learning in Russia dates back } \\
\text { to 1992. Many Russian universities started } \\
\text { immediately implementing distance learning, } \\
\text { following the requirements of the time. But the } \\
\text { quality of computerization did not meet international } \\
\text { standards for real e-education and was reduced to pat- } \\
\text { time distance learning in Russia. }\end{array}$ \\
\hline 2. & $\begin{array}{c}\text { The last decade of the } \mathrm{XX} \\
\text { century }\end{array}$ & $\begin{array}{l}\text { Increased attention to testing programs, presentations, } \\
\text { and the development of electronic textbooks. Experts } \\
\text { in the field of computer technology created the first } \\
\text { software products that form the conditions for remote } \\
\text { interaction between teachers and students. }\end{array}$ \\
\hline 3. & $2000 \mathrm{~s}$ & $\begin{array}{l}\text { EL was actively integrated into traditional education } \\
\text { in a wide variety of formats: as a support for } \\
\text { traditional education (full-time and part-time), as a } \\
\text { higher level of distance education in accordance with } \\
\text { the programs of first and second higher education, } \\
\text { master's degree, advanced training of university } \\
\text { employees, APE and pre-university training. }\end{array}$ \\
\hline 4. & Since 2010 to the present & $\begin{array}{l}\text { The project "Concepts of the Federal Law "On the e- } \\
\text { learning industry" was created. Its main tasks were to } \\
\text { plan and implement scenarios for improving the e- } \\
\text { learning sector in the Russian Federation, and its main } \\
\text { goal was to provide legal support for this process, } \\
\text { leading to the improvement of the national economy } \\
\text { and the progress of our education system. }\end{array}$ \\
\hline
\end{tabular}

Programs aimed at supporting e-learning are being developed in more than 30 countries. In developed countries, even those educational institutions that have existed for more than a century have begun to perceive the presence of online courses in their educational programs as a prerequisite for efficiency. Let us compare this direction in the USA and Russia (table 2).

Table 2.

Use of electronic learning in the United States and Russia

\begin{tabular}{ccl}
\hline № Country & \multicolumn{1}{c}{ Description } \\
\hline 1. $\quad$ USA & $\begin{array}{l}\text { Distance education methods are offered in two hundred universities and } \\
\text { thousands of colleges, where more than } 3 \text { million people are trained. Many } \\
\text { of the world's largest universities offer online courses for free: the University } \\
\text { of California, the Massachusetts Institute of Technology, the Open British }\end{array}$ \\
& \begin{tabular}{l} 
University ("OpenLearn" program), and so on. \\
\hline 2. $\quad$ Russia
\end{tabular} & $\begin{array}{l}\text { The list of Russian institutes, academies and universities offering distance } \\
\text { learning is available on the website http://edu.rin.ru/. In the Russian }\end{array}$ \\
& $\begin{array}{l}\text { Federation, this approach to learning is becoming very relevant in the context } \\
\text { of the implementation of a new generation of FSES, a level-based education } \\
\text { system and the resulting reduction of the classroom load and the creation of } \\
\text { favorable conditions for independent work of students (for which the } \\
\text { electronic format is optimal). }\end{array}$ \\
\hline
\end{tabular}


Analysis, for example, of the informatization of economic education of high school students, showed that, as it is now happening, not only does not solve the problems that have accumulated in economic education, but in some cases it aggravates them and creates new problems. Unsystematic character of traditional economic education is compounded by insufficient control on the Internet, when dozens of authors publish individual fragments of lessons of different quality in the open access; social science teachers, mainly humanitarians, have difficulties in computer science; lack of educational time available for studying the economic sphere is compounded by the loss of time when using ICT because of the lack of clear methodological recommendations for their application; problems with the study of economic theory are compounded by the rejection of the knowledge approach and the focus on pragmatism in the context of the ICT use; general risks and problems of informatization have been added (decrease in the quality of available educational resources; violation of the teacher's monopoly in the educational process, etc.) (Sergeeva, 2019; Narkevich \& Narkevich, 2018; Osipova, 2018; Popov, 2018; Schwarzkopf, 2018; Sergeeva \& Trubakova, 2017; Tsahaeva et al., 2017; Filippova et al., 2019).

\section{Methods and Materials}

In recent studies, the didactic features of an electronic textbook as a source of educational content are presented. The main feature of the electronic textbook is that it includes not only the content of education, but also the selected learning technology. An electronic textbook is an automated training system that includes didactic, methodological, and informational reference materials for an academic discipline, as well as software that allows using them in a comprehensive way to obtain and control knowledge independently. Table 3 shows the features of creating an electronic textbook.

Table 3.

Features of creating an electronic textbook

\begin{tabular}{|c|c|c|}
\hline № & Features & Description \\
\hline 1. & $\begin{array}{l}\text { Organization of educational } \\
\text { information in the form of hypertext }\end{array}$ & $\begin{array}{l}\text { Hypertext - the ability to create a "live", } \\
\text { interactive educational material, provided with } \\
\text { mutual links to different parts of the material. } \\
\text { Hypertext makes it possible to divide the material } \\
\text { into a large number of fragments, connecting them } \\
\text { with hyperlinks in logical chains. The presence of } \\
\text { multimedia - a rich arsenal of ways to illustrate the } \\
\text { phenomenon under study. Multimedia products } \\
\text { use various types of information: computer data, } \\
\text { TV and video information, speech and music. } \\
\text { Multimedia tools are inherently interactive, } \\
\text { meaning that the viewer and listener of multimedia } \\
\text { products do not remain passive. Multimedia } \\
\text { improves the quality of training and allows } \\
\text { keeping the attention of the student. }\end{array}$ \\
\hline
\end{tabular}

2. Modeling of the studied processes and The ability to conduct "computer experiments" in phenomena areas of human knowledge where real experiments are very time-consuming or simply impossible. Availability of a system of self-examination of knowledge, a system of boundary control, compatibility with the lectronic examination system. Ability to evaluate the acquired knowledge. 
Table 4 shows the differences between an electronic textbook and a traditional textbook.

Table 4.

Comparison of an electronic textbook with a traditional textbook

\begin{tabular}{|c|c|c|}
\hline № & Organization of educational content & Description \\
\hline 1. & Set amount of material presentation & $\begin{array}{c}\text { Shortening the chapter text to make it easier to } \\
\text { read on the screen }\end{array}$ \\
\hline 2. & Structure of the material & $\begin{array}{l}\text { Division of the material into several contexts } \\
\text { (for example, mandatory reading, additional, } \\
\text { auxiliary, definitions, etc.) }\end{array}$ \\
\hline 3. & Modularity & $\begin{array}{l}\text { Division of the content of educational material } \\
\text { into modules, in accordance with the } \\
\text { requirements of psychologists }\end{array}$ \\
\hline 4. & $\begin{array}{l}\text { The capacity representation of the } \\
\text { material }\end{array}$ & $\begin{array}{l}\text { Conciseness and brevity of the presentation of } \\
\text { the material with the maximum information } \\
\text { content of the text }\end{array}$ \\
\hline 5. & Graphic software & $\begin{array}{l}\text { Inclusion of graphic software that allows to give } \\
\text { the necessary amount of information with the } \\
\text { brevity of its presentation }\end{array}$ \\
\hline
\end{tabular}

Guided by the need to implement various scenarios for using an electronic textbook, Ya.G. Martyushova identified the following structural units of an electronic textbook (table 5).

Table 5.

Structural units of an electronic textbook

\begin{tabular}{ccl}
\hline № & Structural units & \multicolumn{1}{c}{ Description } \\
\hline 1. & Basic & $\begin{array}{l}\text { The main material is provided with explanatory texts, interactive } \\
\text { illustrations, including theoretical positions and a set of typical tasks }\end{array}$ \\
\hline 2. & Additional & $\begin{array}{l}\text { additional materials in the form of audio and video clips, educational } \\
\text { materials that reveal the history of scientific thought, methods of } \\
\text { scientific knowledge, etc. }\end{array}$ \\
\hline 3. & Practical & $\begin{array}{l}\text { Practical part consisting of blocks of testing, teaching and controlling } \\
\text { the level of learning of educational material tasks, creative tasks of the } \\
\text { student's choice }\end{array}$ \\
\hline 4. & Statistical & $\begin{array}{l}\text { Block of statistical information about the results of students' use of an } \\
\text { electronic textbook }\end{array}$ \\
\hline 5. & Evaluative & $\begin{array}{l}\text { Block of tools for assessing the complexity of tasks, the level of } \\
\text { learning of educational material by students }\end{array}$ \\
\hline
\end{tabular}

To build individual learning trajectories and ensure the variability of personal tasks, users are offered a graph-oriented approach that allows them to formulate two didactic principles for designing an electronic textbook (table 6).

Table 6.

Didactic principles of the electronic textbook designing

\begin{tabular}{ccc}
\hline № & Didactic principle & Description \\
\hline 1. & $\begin{array}{c}\text { Principle of formation of individual } \\
\text { educational trajectories by means of } \\
\text { graph-oriented approach }\end{array}$ & $\begin{array}{c}\text { The essence of the graph-oriented approach is to } \\
\text { structure the content in different sections, ranked } \\
\text { according to the logic of the course, and give each } \\
\text { element of content a numerical indicator of the } \\
\text { complexity of its implementation. }\end{array}$ \\
\hline 2. & $\begin{array}{c}\text { Principle of adaptability of an } \\
\text { electronic textbook }\end{array}$ & $\begin{array}{c}\text { It is implemented on the basis of feedback and } \\
\text { statistical processing of user results. }\end{array}$ \\
\hline
\end{tabular}




\section{Results and Discussion}

Our empirical research was conducted in specialized economic classes of Moscow universities that signed contracts with schools for admission of graduates to specific universities. Let us consider which lines of textbooks are suitable for integration with information and communication technologies and can be taken as the basis of the model of economic education. Textbooks on social science were developed by scientists and teachers of the Humanities; textbooks on Economics - by academic economists. Social science textbooks have a predominantly descriptive style of presentation. Focusing on humanist teachers, the authors of these textbooks avoid analytical (mathematical) and graphical forms of presentation of educational material. At the same time, it becomes difficult to consider macro- and microeconomic models in full: content elements, key economic concepts are given in fragments, in isolation from their connections: functional, logical, hierarchical, etc. These textbooks are insufficiently illustrated with diagrams and poorly structured, which does not really correspond to modern economic theory. As a result, the predominance of the reproductive form, as for independent productive activity, students will have to get an idea of the objective connections of economic concepts and dependencies expressed by formulas. From the point of view of the topic of this study, it can be concluded that the imposition of ICT on such a content structure is ineffective, as it will require a lot of additional refinement. Textbooks on Economics written by economists, not teachers, are difficult for high school students to understand (note in parentheses, and for teachers of Humanities, they are also difficult); they are mostly translated, and do not take into account the peculiarities of the Russian economy. At the same time, they are well structured, which makes it possible to illustrate macro - and micro-economic models, their elements and main connections with the help of modern multimedia; they represent the material both in analytical and graphical form. This construction of economic content could provide an activity approach, but, as shown above, does not implement it. The content structure of such textbooks, in our opinion, is more consistent with the architecture of an electronic textbook, which involves the use of multimedia and hypertext, splitting the content into separate modules without violating the logic of studying the content.

Let us look at the teaching methods used in Economics lessons. Let us turn to the best practices of Economics teachers who widely use so-called innovative methods and highly evaluate their effectiveness. Thus, the following forms and methods of training are recognized as effective: business game, computer modeling, problem discussion, testing, training, seminar, preparation of reports, and organization of school companies. However, the majority of teachers, as shown by the analysis of the survey results, even today, after twenty years, do not have a sufficient understanding of innovative methods of teaching Economics. Moreover, in the practice of teaching economic content, there is a certain imbalance between the demand, relevance of economic knowledge and the level of economic training of social science (Economics) teachers. Highly appreciating the importance of the economic sphere, teachers are extremely low on the level of their own training in Economics, the level of knowledge of modern methods of teaching Economics. The data obtained indicate that $90 \%$ of the teachers surveyed considered it important to study Economics in high school. At the same time, only $38 \%$ of social science teachers consider themselves trained in Economics. The respondents also included Economics teachers whose average level of training in economic theory is not much higher than the average in social studies. In table 7, the topics of the course "Social Science" are ranked according to the decreasing percentage of teachers who consider themselves fully prepared for their teaching. 
Table 7.

The level of teachers' training in the content lines of social science

\begin{tabular}{cc}
\hline $\begin{array}{c}\text { Sections of the course } \\
\text { "Social Science" }\end{array}$ & $\begin{array}{c}\text { \% of respondents who consider themselves fully } \\
\text { prepared for this topic }\end{array}$ \\
\hline Political science & 73 \\
\hline Right & 69,5 \\
\hline Sociology & 67,5 \\
\hline Cultural studies & 61 \\
\hline Global world & 55 \\
\hline Information society & 53 \\
\hline Philosophy & 45 \\
\hline Economics & 38,5 \\
\hline Religious studies & 38,5 \\
\hline Social psychology & 37 \\
\hline
\end{tabular}

Teachers have not enough methodological tools necessary for studying Economics at the current level and are forced in mass practice to rely mainly on the lecture form of classes. Teachers are unanimous about the need for changes in the system of professional development. Even taking into account that teachers' self-esteem is subjective and can be either overstated or underestimated, such statistics indicate the need to pay attention to the opinion of teachers.

We turned to the teachers' opinion about what should be the ideal textbook on Economics (social science)? In 2010-2015, employees of the Institute of Education Development Strategy of the Russian Academy of Education conducted a survey of teachers. More than 300 teachers from Moscow, St. Petersburg, Arkhangelsk, Bryansk, Chelyabinsk, and Nizhny Novgorod were interviewed. Various characteristics of the textbook are proposed for consideration: the degree of detail of the theoretical material, the prevailing style of presentation, the nature of the educational material, illustrations, and textbook support.

Below there are the results of a survey of Economics and social studies teachers on teaching Economics in basic and high school. Teachers were asked to express their opinions on:

- choosing the appropriate form of economic education organization: independent subject (basic level); independent subject (advanced level); as a section in the social science course; optional or elective course; lessons with an external teacher (consultant);

- the development of the content of economic education, the choice of priority topics for study: the basics of economic theory, the basics of entrepreneurship, the basics of financial literacy, etc.;

- expanding the methodological apparatus, combining traditional and innovative forms of training;

- a high-quality textbook on Economics: the prevailing style of presentation, the nature of the material, illustrations and support for the textbook;

- the feasibility of using electronic educational resources for various purposes, including taking into account their own experience in this process.

- As a result, the following information was obtained on economic education in Russian schools.

- Currently, school economic education is presented in the following forms:

- section "Economics" in the course of social studies (in basic school $44 \%$ of respondents' responses and in high school-37\%);

- independent subject (in 24\% at the basic level in high school and at the advanced level in high school in $20 \%$ of schools); 
- elective courses on specific economic issues: "Entrepreneurship", "Financial literacy", "Consumer Protection", "Family economy" (10\% in basic school and 14\% in high school).

Elective courses are usually presented in schools where Economics is taught as an independent subject at the basic level. This form can be considered as an intermediate step between the basic and advanced level of study of Economics.

Choosing the most promising form of organization of school economic education in the basic school, teachers prefer the course "Social Science" (economic sphere). As an independent subject, "Economics" in the main school is considered inappropriate: $10 \%$ of teachers offer to study Economics in 5-7grades, $20 \%$ - in 8 grade and 30\% - in 9grade.

For high school, most teachers believe that the "Social Studies" course should be supplemented with Economics as an independent subject, and only $16 \%$ of teachers believe that the economic section in the "Social Studies" course will be enough for high school students. Let us note that all teachers in schools where Economics is already organized as a separate subject approve of this choice.

At the advanced level, 34\% of teachers are ready to study Economics in 10-11grades, and $19 \%$ of teachers believe that an external teacher (consultant) should conduct Economics lessons. In addition, teachers consider it necessary to conduct additional optional and elective courses on Economics: in 8 grades $-17 \%$ of respondents, in 9 grades $-31 \%$, in $10-11$ grades $-20 \%$.

Choosing priority topics for study, teachers evaluated the feasibility of studying the following issues in Economics lessons: fundamentals of economic theory, basics of entrepreneurship, basics of financial literacy, basics of consumer culture, history of economic studies, management, marketing, environmental issues and family economy. The questionnaire provided for the study of economic content both in the framework of an independent subject "Economics" and in the framework of an integrated course "Social Science" in the section "Economic sphere". At the same time, teachers were asked to evaluate their own level of training on each topic of economic content. Among the issues that should be covered in the content of economic education, applied topics received more than 50\% of the votes: management, marketing, basics of entrepreneurship, and basics of financial literacy. $49 \%$ of participants name the basics of economic theory. When choosing which course should study certain economic issues: in the course "Economics" or in the course "Social Science", the teachers answered that in the course "Social Science" it is more logical to consider three topics: "Basics of consumer culture" (49\%), "Economics and ecology" (44\%), "Family economy"(52\%). Other topics of economic content are selected by teachers for study in the course of Economics.

The data obtained showed that only $35 \%$ of teachers who teach economic content in one form or another consider themselves trained in the basics of economic theory. This is even slightly lower than five years ago (38\%). To clarify, only $20 \%$ of respondents know all economic topics, and $17 \%$ do not know any topics. It is characteristic that not only economic theory, but also applied economic topics chosen by the majority of teachers, are familiar to only a third of teachers, according to their own assessment. This situation, in our opinion, cannot be considered satisfactory. FSES-2 provides for a massive transition to advanced study of Economics in high school. The results of the survey suggest that the study of Economics at an advanced level today is not provided by the readiness of teachers of social science and Economics for such a transition.

Teachers were asked to speak about the need to expand the methodological apparatus in Economics lessons, a combination of traditional and innovative forms of education. The 
questionnaire provides options (regularly or occasionally) for using various forms and methods of training.

According to teachers, students should regularly work with didactic materials and textbooks, and occasionally participate in role-playing games, work in small groups, and engage in design and research activities. Less than half of teachers approve of the lecture form as permanent. The advantage is given to active forms of learning, an active approach and independent work of students. Teachers gave suggestions for the formation of an "ideal" textbook of economic content regarding the prevailing style of presentation, the nature of the material, illustrations, and textbook support. The following characteristics of the new generation of Economics textbook are named:

- a summary of the material in the basic level textbook was preferred by $74 \%$ of respondents, an adapted style of presentation - $61 \%$, presentation of different points of view- $67 \%$;

- all types of illustrations (about 70\%): logic diagrams, examples from Russian (to a lesser extent - foreign) life, statistics, photos and drawings;

- all types of support (about 70\%): dictionary, workshop, guidelines for teachers, electronic support on disk.

\section{Conclusion}

Information and communication technologies have a high pedagogical potential: expanding information environment of the educational process, expanding interdisciplinary connections, a variety of types of work with students, optimization of education process, a wide illustrative opportunities, development of learning activities, quick and effective control, and didactical advantages of e-textbook as a source of educational information. Along with the wide possibilities of using ICT, it is associated with certain risks (control over the strategic resource - the content of economic education is lost; the quality of available educational resources is reduced; the teacher's monopoly in the educational process is violated, etc.). According to the researchers, the level and effectiveness of the use of ICT in education depends on the choice of the priority model of education and the principles on which this education is based.

\section{References}

Abuzjarova, M.I. (2018). Tendencies, law of development and economic content of innovative entrepreneurship. Modern Economy Success, (1), 43-50.

Aminova, D. K., \& Tsakhaeva, A. A. (2018). Effective preparation of the future psychologist as one of the elements of the security education system. International Journal of Medicine and Psychology, 1(3), $40-47$.

Ashmarov, I.A. (2018). Some approaches to the study of the USSR' military economy in the soviet and russian national historiography. Historical Bulletin, 1(2), $19-31$.

Badakhova, I.T. (2017). Formation of professionally significant qualities of future managers in the training process forming. Modern Scientist, (7), $81-84$.

Bolotin, I.S., Mikhaylov, A.A., \& Sorokina, N.D. (2017). Functional literacy of students in terms of introduction of information technologies (on the example of research among the students of MAI). Modern Scientist, 1(1), 160-163.

Borisov, V.I. (2018). Influence of the food crisis for the revolution of the working mass of russia in the years of the first world war (August 1914 - February 1917). Historical Bulletin, 1 (2), $49-55$.

Borisova, M.V., Musokhranov, A.Yu., Sidorova N.A. (2018). Use of fitness directions elements on physical education classes and their psychomatic impact on students of the special medical group. Modern Scientist, (1), 6 - 9. 
Borovikova, T.V. (2017). Methodological bases of formation of the intellectual potential of territories in the conditions of innovative economy. Modern Economy Success, (6), 46 49.

Bugreeva, A.S. (2019). Questions of efficiency of using digital technologies in the system of higher vocational education. Modern Scientist, (6), 86 - 91.

Filippova, E.O., Marchenko, L.O., \& Levich, S.N. (2019). The role of intellectual abilities at the stage of professional training selection. Modern Scientist, (5), $39-45$.

Gadzaov, A.F., \& Dzerzhinskaya, M.R. (2018). Mathematical methods of analysis of the periodic components of economic processes. Modern Economy Success, (1), 14 - 18.

Gadzhieva, U.B. (2018). Socialization of personality as a factor in the mental, intellectual and spiritual-moral development. International Journal of Medicine and Psychology, 1(Issue 2), $7-20$.

Gasanova, P.G., Daudova, D.M, Kabieva, R.A., \& Tsahaeva, A.A. (2017). Moral qualities of businessmen in public con-sciousness. Modern Scientist, 1(1), 209 - 211.

Gnatyuk, S.N., \& Pekert, N.A. (2018). Education as a factor of sustainable development of agriculture. Russian Economic Bulletin, 1(3), 18 - 27.

Korotkov, S.L. (2019). Interdisciplinary approach to the learning process. Modern Scientist, (5), $18-23$.

Kryuchkova, K.S. (2018) Modular training of future teachers with the use of information technologies in the conditions of virtual academic mobility. Modern Humanities Success, 2(4), $9-14$.

Kuznetsov, A.A., Ignatyeva, T.A., \& Kuznetsov, A.O. (2018). Strategy and key elements of competitiveness. Modern Economy Success, (1), 25 - 29.

Makarova, V.V. (2019). Professional activity of the bachelor of management in the context of social interaction competence. Review of Pedagogical Research, 1(1), $19-25$.

Narkevich, L.V., \& Narkevich, E.A. (2018). Financial condition analysis in the crisis management system. Russian Economic Bulletin, 1 (4), 10 - 24.

Osipova, M.B. (2018). Tendencies of development of educational practice of the modern educational organizations. Modern Humanities Success, (1), 10 - 13.

Popov, V.P. (2018). Methodological aspects of teaching economic disciplines in a multi-level system of education. Modern Humanities Success, (3), 10 - 16.

Schwarzkopf, N.V. (2018). Improving the use of data mining technology as a way of reducing credit risk. Russian Economic Bulletin, 1 (1), 10 - 18.

Sergeeva, M.G. (2019). To a question of formation of administrative culture of the manager in education. Review of Pedagogical Research, 1(1), $26-33$.

Sergeeva, M.G., \& Trubakova, D.I. (2017). Teacher's reflection formation as factor of effectiveness children's social intelligence forming. Modern Scientist, (7), 62 - 64.

Tsahaeva, A.A., Aminov, U.K., \& Aminova, D.K. (2017). Driving forces of the development of adaptive behavior of personality: methodological considerations. Modern Scientist, (8), $44-47$. 